\title{
Krzysztof Łukasiewicz
}

ORCID: 0000-0002-9657-3385

Uniwersytet Wrocławski

\section{Coś więcej niż filozofia sztuki. Wokół Simmlowskich rozważań o Michale Aniele}

Abstrakt: Georg Simmel interesował się twórczością Michała Anioła na wszystkich etapach rozwoju swojej koncepcji. Choć poświęcił temu artyście tylko dwie prace, to podejmując inne tematy, często przywoływał jego nazwisko. Wczesny, bo z 1889 roku, artykuł Simmla dotyczył poezji Buonarrotiego, podczas gdy w późniejszej (z 1910 roku) i znaczenie obszerniejszej rozprawie badacz interpretował jego dorobek w perspektywie filozofii kultury. W następnym roku Simmel opublikował artykuł Pojęcie i tragedia kultury, którego tematykę zapowiadały rozważania o twórcy Dawida. Podjęte w nich zostały problemy autonomii sztuki, jej relacji do religii i etyki, a także kwestia charakteru i dynamiki nowoczesności. Odmiennie ich ujęcie reprezentowali Max Weber i Ernst Cassirer, których w koncepcji Simmla niepokoiło emfatyczne i silnie związane ze sferą estetyczną pojmowanie kultury.

Słowa-klucze: filozofia kultury, sztuka, estetyzm, tragizm, religia, etyka, nowoczesność

O motywacjach, uzasadnieniach i roli dziewiętnastowiecznych podróży do Włoch napisano sporo. Sam miałem już okazję scharakteryzować, jak przedstawiało się to w wypadku koncepcji Georga Simmla, a zwłaszcza jego ujmowania kultury ${ }^{1}$. Podstawowe znaczenie miała tutaj dawna sztuka włoska, a spośród jej wielkich twórców specjalne znaczenie niemiecki filozof przypisywał twórczości Michała Anioła. Co prawda, nie był odosobniony ${ }^{2}$, lecz jego rozważania o tym

${ }^{1}$ K. Łukasiewicz, Alpy, Włochy i rozumienie kultury, „Prace Kulturoznawcze” 17, 2015, s. 63-70. Ponadto zob. P. Giacomoni, Georg Simmel und Italie, „Simmel Studies” 2008, nr 1, s. 149-168, a w ogólniejszym odniesieniu do rozwoju niemieckiej myśli o kulturze A. Gipper, Die Entstehung der Kulturwissenschaft in Deutschland und das Paradigma der italienischen Renaissance, [w:] Kultur, Übersetzung, Lebenswelten Beiträge zu aktuellen Paradigmen der Kulturwissenschaften, red. A. Gipper, S. Klenge, Würzburg 2008, s. 29-50.

2 Zob. A.D. Biemann, Michelangelo und die jüdische Moderne. Poetik, Exegese und Narrative, Göttingen 2016. Poza Simmlowskimi w książce tej analizowane są poglądy Heinricha Heinego, Franza Rosenzweiga, Sigmunda Freuda, Hermanna Cohena oraz Martina Bubera. 
artyście wyróżniały się płynnym przechodzeniem od zagadnień filozofii sztuki do filozofii kultury.

Obszerna rozprawa Simmla Michelangelo ukazała się w drugim numerze „Logosu” z roku 1910, a jej tytuł został znacząco uzupełniony: Ein Kapitel zur Metaphysik der Kultur; znacząco również w tym sensie, że zapowiadającym ${ }^{3}$ poniekąd następny ważny artykuł badacza na łamach tego samego pisma, a mianowicie Der Begriff und der Tragödie der Kultur („Logos” 1910/1911, z. 2). Przypomnieć jednak trzeba, że nie była to pierwsza praca Simmla o włoskim artyście, gdyż u początków swojej twórczości - w 1889 roku — opublikował pracę o nim jako poecie ${ }^{4}$. Sporą rolę w podjęciu tego tematu odegrały studia Simmla nad językiem starowłoskim, z którego zdawał jeden z pobocznych egzaminów. Wiąże się z tym geneza innej z jego pierwszych obszerniejszych rozpraw, a mianowicie Dantes Psychologie (,Zeitschrift für Völkerpsychologie und Sprachwissenschaft” 15, 1884), w której wyraźnie jeszcze pozostawał pod wpływami poglądów Moritza Lazarusa i Heymana Steinthala — twórców koncepcji psychologicznej, ale o sporym potencjale i znaczeniu dla kształtowania się usamodzielnionej myśli o kulturze.

Drugi, późniejszy tekst o Michale Aniele — oprócz wielu innych odmienności — od pierwszego różni się materiałem analizy, który stanowi tu przede wszystkim twórczość rzeźbiarska i malarska tego artysty. Zdecydowana większość prac Simmla z dziedziny filozofii sztuki odnosi się przy tym do plastyki ${ }^{6}$, a należy

${ }^{3}$ Willfried Gessner - autor najobszerniejszej dotychczas książki o Simmlowskiej myśli o kulturze (Der Schatz im Acker, Weilerswist 2003) - nie eksponuje tego; za to w analogicznym opracowaniu Ingo Meyera dotyczącym Simmlowskiej estetyki (Georg Simmel Ästhetik. Autonomiepostulat und soziologische Referenz, Weilerswist 2017) rozprawie z „Logosu” o włoskim artyście poświęcony został osobny rozdział: ,, Michelangelo”: Leben transgredirt Form (s. 127-136). Pogląd na to, jak prezentuje się przywoływana tutaj rozprawa $\mathrm{z}$ „Logosu” na tle całości dzieł jej autora, pozwala wypracować wydany z okazji setnej rocznicy jego śmierci Simmel-Handbuch: Begriffe, Hauptwerke, red. H.P. Müller, T. Reitz, Frankfurt am Main 2018, s. 365-369.

${ }^{4}$ G. Simmel, Michelangelo als Dichter, „Vossische Zeitung” 1889, nr 36, s. 6-9.

${ }^{5} \mathrm{Na}$ marginesie warto odnotować jedno z nowszych ujęć rozwoju koncepcji Simmla. Według Efraima Podoksika (In search of unity: Georg Simmel on Italian cities as works of art, „Theory, Culture and Society" 2012, nr 6, s. 101-123) dla okresu, w którym powstała między innymi praca o Dantem, najważniejsza dla Simmla była kwestia ,jedności w wielości”; dla następnego, w którym opublikował książkę Nietzsche und Schopenhauer (1906), ,jedność versus wielość”; dla trzeciego, w którym tak wiele pisał o Goethem i Rembrandcie, ,jedność transcendentująca wielość". Zachowane zostało tu, najczęstsze w literaturze przedmiotu, rozróżnienie trzech etapów w rozwoju myśli autora Filozofii pieniądza, ciekawsze jest zatem nawiązanie w tym wypadku do podzielanego także przez Simmla określania sztuki jako ,jedności w wielości”. Warto w tym miejscu podkreślić, że artykuł o poezji Michała Anioła należy do okresu pierwszego, a rozprawa o nim w „Logosie” — do trzeciego.

${ }^{6}$ Zob. B. Smitmans-Vajda, Die Bedeutung der bildenden Kunst in der Philosophie Georg Simmels, Aachen 1997. Nie znaczy to, że Simmlowskich poglądów nie daje się odnosić do nowych gatunków sztuki - zob. D. Fritsch, Georg Simmel im Kino. Die Soziologie des frühen Films und das Abenteuer der Moderne, Bielefeld 2009. 
podkreślić - pomijając względy biograficzne — że to uprzywilejowanie wzroku ma swój odpowiednik w jego socjologii. Kiedy zatem Simmel odpowiadał na fundamentalne pytanie, ,jak możliwe jest społeczeństwo”, w znacznej mierze podnosił kwestie, o których traktuje także jego artykuł Problem portretu - w tym co najmniej stopniu, w jakim tu i tam chodziło o poznanie i rozumienie ludzkiej indywidualności. Jakkolwiek więc w rozprawie w „Logosie” cytowane była wiersze Michała Anioła, nawet te same, które przytaczane były w tekście o tym poecie z roku 1889, stanowiły one uzupełnienie lub wzmocnienie zasadniczo na innej drodze osiągniętych stwierdzeń. Nabierały też wyrazistości na tle ogólnego zarysu rozwoju włoskiej sztuki doby renesansu, którą Simmel nakreślał nie tyle mimochodem, ile dla uchwycenia odrębności autora Mojżesza. Dla niemieckiego filozofa w zasadniczym stopniu budowało ją wyczucie tragiczności i wyrażenie tego środkami artystycznymi, co zostało podkreślone i uogólnione w rozszerzonej formule tytułowej rozprawy w „Logosie”. Simmel wskazywał jednak na to, już analizując poetycką twórczość Michała Anioła, która dla niego ogniskowała się wokół trzech zagadnień: miłości, cierpienia i zwrotu ku Bogu. Ich „najbardziej wewnętrzny" spośród doświadczanych przez ludzi charakter sprawiał, że pomimo niemożliwości zadomowienia się w świecie dzieł Michała Anioła odczuwamy bogactwo jego osobowości. Poczucie wyobcowania z niego, jakiego doznawał odbiorca, wynikało zdaniem Simmla z ogromnego przeciwieństwa między stroną zewnętrzną i wewnętrzną twórczości Michała Anioła, większą nawet niż u Ludwiga Beethovena ${ }^{7}$, z którym łączyć ma go chociażby siła religijnego przeżywania:

To miarą naszych bólów i rozpaczy,

Czy mniej, czy więcej w kim czułego ducha;

Jakie są we mnie, moc twa, Panie, baczy ${ }^{8}$.

Właśnie wiersze najmocniej poświadczały o uwewnętrznieniu wszelkich osobistych i ideowych problemów włoskiego twórcy, gdyż w świetle bardziej ogól-

${ }^{7}$ Aspirujący do kariery akademickiej Simmel przygotował rozprawę Psychologisch-ethnologische Studien über die Anfänge der Musik (1882), która jednak została oceniona negatywnie. Im bardziej bowiem autor oddalał się od pozytywizmu, tym łatwiej było mu się z tym niepowodzeniem pogodzić. Wszakże problematyki muzyki - mimo znaczenia, jakie dla niego mieli Arthur Schopenhauer i Friedrich Nietzsche - nie podjął już szerzej, choć stosunkowo rzadkie zdania o muzyce, jakie potem formułował, oraz wspomnienia jego współczesnych dowodzą, że zachował na nią dużą wrażliwość. Zob. E. Hüppe, Musik und Ethos. Eine soziologisch-ästhetische Spurensuche, [w:] Georg Simmel und das Leben in der Gegenwart, red. R. Lautmann, H. Wienold, Wiesbaden 2018, s. 381-396.

${ }^{8}$ M.A. Buonarroti, Poezje, przeł. L. Staff, Warszawa 1956, s. 35. W pochodzących z początku XX wieku opracowaniach dotyczących autora fresków w Kaplicy Sykstyńskiej dawano niekiedy wyraz świadomość tego, jak skomplikowana była jego koncepcja miłości. O tym traktuje na przykład artykuł Władysława Kozickiego Eros. Fragment z życia i twórczości Michała Anioła („Krytyka" 1910 , t. 2, s. 292-297, t. 4, s. 56-71, 164-170, 228-238, 315-323). Ukazał się on w krakowskiej „Krytyce”, choć pierwotnie wchodził w skład monografii Kozickiego Michał Anioł (Lwów 1908), w której wypadku wydawcy nie zdecydowali się na pełną wersję tekstu. 
nych twierdzeń Simmlowskiej filozofii sztuki w poezji to, co wewnętrzne, psychiczne, jest bezpośrednią materią kształtowania, podczas gdy plastyka docierać tam może jedynie okrężną drogą. Kontrast między liryczną formą a wyrażonymi w niej zwątpieniami nękającymi tak „tytaniczną naturę” jak Michał Anioł, wzbudza zdaniem Simmel w odbiorcy ,tragiczne wzruszenie”, które sprawia, że przestaje być on tak odległą, że aż obcą dla nas wielkością. Niemiecki filozof nie porównywał Michała Anioła z innymi poetami owego czasu, nie opisywał szczegółowo jego metaforyki. Podkreślał jednak jego upodobanie do madrygału i sonetu - form literackich związanych pierwotnie z erotyką i dość skonwencjonalizowanych. Uznawał, że tkwił w tym całkiem świadomy zamiar oddania zmiennego oddziaływania między powagą a przesadą. W bardziej ogólnym czy — ściślej ujmując - formalnym planie pojawiała się tutaj kwestia stosunku do konwencji, która w tym wypadku miała być wykorzystana do zatajenia czy utrzymania niepewności, w jakim stopniu poważnie traktuje się to, co się wyraża w tak określony sposób.

Zagadnienie miłości, o którym szerzej i bardziej samodzielnie traktują późne prace filozoficzne Simmla, stało się centralne w jego rozważaniach o poezji Buonarrotiego i punktem odniesienia do pozostałych dwóch jej tematów. Odcinając się od biograficznego w istocie pytania, jaki był tegoż stosunek do Vittorii Colonny, dla niemieckiego filozofa takie choćby jego wersy:

A że w swych oczach masz raj nieśmiertelny,

Więc, by tam wrócić, gdzie wpierw cię kochałem,

Uciekam, płonąc, pod twych brwi ochronę ${ }^{9}$,

dowodziły, że w tym ujęciu miłości najważniejsze jest przeciwieństwo między osobowością osoby kochającej i kochanej.

$\mathrm{Z}$ kolei fragment:

O mojej woli twa wola stanowi,

Myśli me rodzą się z serca twojego,

Oddech twój życie w moich słowach wznieca.

Sam przez się rówien jestem księżycowi,

Z którego tyle li oczy dostrzegają

W niebiosach, ile go słońce oświeca ${ }^{10}$,

pochodzący z innego sonetu, odczytywał jako taki wyraz podziwu i oddania osobie ukochanej, że jednocześnie tkwi w nim „tragiczne odczucie” własnej znikomości kochającego. Uprzytamniając to, miłość może z tego wyzwolić, lecz wymaga jednak oddalenia się od pierwotnej podniety. Tyle tylko, że na tej drodze traci znaczenie konkretność przedmiotu miłości. Być może w tym momencie Simmel nawiązywał do Goetheańskiej idei „wiecznej kobiecości”, bezpośrednio

\footnotetext{
${ }^{9}$ M.A. Buonarroti, op. cit., s. 51.

${ }^{10}$ Ibidem, s. 60.
} 
za to wskazywał na filozofię renesansową. Od Rafaela, który zdawał się nie dostrzegać brzydoty, Buonarroti miałby jednak różnić się tak silnym jej odczuwaniem, że z tego właśnie wyrastała tęsknota i wizja wyższego piękna. W obliczu opanowującej go miłości, która z swej istoty, a nie z przypadku, nie gwarantowała błogiego szczęścia, zaostrzało się u Michała Anioła przeciwieństwo tego, co zewnętrzne, i tego, co wewnętrzne; ciała i ducha, dnia i nocy.

O cieniu śmierci, który koisz całą

Niedolę duszy wszelkiej, sercu wrogą,

Ostatni, błogi uciśnionych leku ${ }^{11}$.

Simmel nazywał Michała Anioła ,poetą nocy”, gdyż łączył z nią to, co specyficznie ludzkie, przede wszystkim odczuwanie jej grozy (w przeciwieństwie do dziennego światła ważnego dla wszystkich istot naturalnych). Zasługiwał on zdaniem badacza także na miano „fanatyka piękna”, albowiem chodziło o takie tegoż pojmowanie, które przechodzi poza sferę tego, co widzialne.

Temat oczu i wzroku pojawiał się wielu sonetach Michała Anioła, ale powab naoczności miał być jedynie mostem do nadzmysłowości. Jedynie wtedy na tym, co naturalne, może kształtować się godność człowieka i jego obojętność na cierpienie, a tracący na znaczeniu sensualny wymiar miłości przynosi zakochanemu pojednanie z samym sobą. Dla autora Filozofii pieniądza takie ujęcie zbliżało Michała Anioła do poetów modernistycznych, których wrażliwość zmysłowa zdaje się mieć źródło w refleksji, choć równocześnie - dzięki namiętności i zdolnościom artystycznym - włoski poeta unikał jedynie nadawania problemom duchowym sensualnego wymiaru. Simmel podkreślał w związku z tym, że wychodząc od zmysłowego piękna i dzięki pozaczasowemu pięknu formy, dla Michała Anioła sztuka ostatecznie wskazywała na niebiańskie wyżyny, podobnie jak niezmysłowe piękno ukochanej prowadziło go ku temu, co wieczne. Niemiecki filozof dostrzegał tu wyraźne wpływy neoplatońskich idei ponadzmysłowości piękna i miłości, z czym wiązał także religijny ton liryki Buonarrotiego. Odnajdywał w niej wyraz wahania między wiernością kościelnej doktrynie a panteizmem, między entuzjazmem dla piękna a jego religijną deprecjacją, między tęsknotą do Boga a oskarżaniem go o obojętność, między wrażliwością na ziemskie uroki a żalem straconego na nie czasu... Co istotne, nie wynikało to z niezdecydowania, lecz z ,tragicznego odczuwania" zewnętrznego, międzyludzkiego i wewnętrznego świata ${ }^{12} . Z$ tej również racji Simmel zawieszał odpowiedź na pytanie, czy Michał Anioł osiągnął w miłości wyższą harmonię tego, co w nim zewnętrzne, i tego, co wewnętrzne; czy zaspokoił swą autentyczną i głęboką potrzebę zbawienia. Ale w zdaniu, któ-

11 Ibidem, s. 42.

12 Podnoszący między innymi filozoficzną kwestię tragedii Michał Sobeski wyrażał podobną myśl: „Michał Anioł nie szukał problematów. [...] On nosił tysiące problematów w duszy, bo dla niego wszystko było problematem" — idem, Przędziwo Arachny, Kraków-Warszawa 1909, s. 53. 
rym zamykał przypomnianą tu rozprawkę, przypominającym o nieskończonym charakterze wielu dzieł włoskiego artysty, kryła się jednak pewna sugestia:

Podobnie jak postaci Michała Anioła, tak ostatnią i decydującą tragedią jego życia stało się to, że ludzkość nie znalazła jeszcze trzeciego królestwa ${ }^{13}$.

Rozprawę w „Logosie” od artykułu w „Vossiche Zeitung” dzieli ponad dwadzieścia lat, w ciągu których Simmel sporo opublikował, a jego zainteresowania i koncepcje uległy różnym przekształceniom. Anonsuje to jedynie problem dopominający się o osobne rozważenie, nawet gdy przyznawać, że chodzi o szersze zagadnienie odniesione tylko w tym wypadku do węższej dziedziny, to jest poglądów na sztukę i estetykę ${ }^{14}$. Obszerny artykuł poświęcony Michałowi Aniołowi, jak już zostało wskazane, przez samego autora traktowany był jako przyczynek do metafizyki kultury, co od razu zapowiadało sposób potraktowania tytułowego, wydawałoby się monograficznego, zadania. Dla zrozumienia owego podtytułu, jak też całości wywodu Simmla istotne jest pojmowanie metafizyki, którą filozof definiował nie poprzez wskazywanie na ostateczny charakter jej zadań i orzeczeń, lecz jako swoistą postawę wobec świata. Takie ujęcie upoważniło Ralfa Konersmanna do przywołania kategorii habitusu, co dodatkowo badacz połączył z charakterystyczną dla Simmla tendencją do odsłaniania względności wszelkich określeń i ciągłego poszukiwania odmiennego potraktowania danej kwestii ${ }^{15}$.

Punkt wyjścia rozprawy o Michale Aniele stanowi przekonanie o dualistycznej strukturze nowoczesności, która wszelkie zjawiska ujmuje poprzez przeciwieństwa. $Z$ niemożności ujęcia jedności zjawisk wynika w tym samym stopniu teoretyczne co praktyczne pytanie, jak — mimo wszystko - ją uchwycić ${ }^{16}$. Z racji różnorodności życiowych treści i ludzkich ograniczeń nie daje się tego uczynić realnie, ale osiągane jest to symbolicznie, a zatem w tym, co zmysłowe, może wyrazić się to, co inteligibilne.

13 G. Simmel, Michelangelo. Ein Kapitel zur Metaphysik der Kultur, „Logos” 1910/1911, z. 2, s. 227. Jeśli nie podano inaczej, thum. K.Ł.

${ }^{14}$ Literatura sekundarna na ten temat jest obfita, a — pomijając starsze prace — wskazać warto, że dla drugiego numeru „Simmel Studies” z 2001 roku Schwerpunkt stanowiło zagadnienie Simmel und Ästhetik, a w następnym roku na łamach tego samego pisma Graciela Schuster pytała: Ist eine Theorie der Kunst möglich? („Simmel Studies” 2002, nr 2, s. 212-229). Jednak dopiero w 2017 roku ukazała się cytowana już monografia Meyera.

15 Zob. R. Konersmann, Der Metaphysiker der Diesseits. Entwickelte Korrespondenzkultur - der Philosoph und Soziologe Georg Simmls in seiner Briefe, ,Neue Zürcher Zeitung” 23.09.2008, https:// www.nzz.ch/der_metaphysiker_des_diesseits-1.887565 (dostęp: 22 września 2018). Odnośnie do tej kwestii polecić można także pracę Adolfa Heinricha Erkenntnistheorie auf dem Weg zur Metaphysik (München 1999) oraz rozdział Kulturtheorie und Metaphysik: Simmels Philosophieverständnis z książki Anniki Schlitte, Die Macht des Geldes und die Symbolik der Kultur (Padeborn 2012, s. 160-190).

${ }^{16} \mathrm{O}$ tym, jak ważna dla autora Über sociale Differzierung była problematyka jedności, przekonuje stara praca Maxa Nobsa, Der Einheitsgedanke in der Philosophie Georg Simmels, [b.m.w.] 1926. 
Simmel w dziejach sztuk plastycznych odnajdywał różnorodne rozwiązania tego problemu. W późnej pracy Konflikt kultury nowoczesnej $(1918)^{17}$, w której naszkicował koncepcję idei podstawowych dla każdej epoki, uznał, że w antyku była nią natura; w artykule z 1911 roku dowodził, że grecka plastyka skupiała się tak silnie na tym, co naturalne, że dualizm stawał się nieodczuwalny. W renesansie, którego odmienność różnych faz Simmel wyraźnie dostrzegał, raz przyznawano przewagę temu, co naturalne, kiedy indziej temu, co duchowe. Dopiero w portretach quattrocento wyraźne stały się wysiłki zindywidualizowania zarówno ducha, jak i ciała, ale udawało się to jedynie w malowaniu głowy. Takie częściowe artystyczne odzwierciedlenie niepowtarzalnej indywidualności nie likwidowało jeszcze dualizmu jako takiego; nie udało się to nawet Botticellemu, który choć uwzględniał już całą ludzką postać, to w dalszym ciągu związanej u niego z ciałem duszy brakowało ziemskiej substancjalności. Jeśli sens renesansu wyznacza dążność do scalenia przeciwstawianych sobie przez chrześcijaństwo natury i ducha, to w Simmlowskim ujęciu w plastyce odpowiadał temu problem stosunku formy ciała do ruchu, który w jego ocenie znalazł swoje ostateczne rozwiązanie dopiero w dziełach Michała Anioła. W nich bowiem dualizm został przezwyciężony, wszelkie nastroje i namiętności duszy przeniknęły w formę artystyczną; formę, która bezpośrednio oddaje ich dynamikę, a przez to i jedność. Wzajemne określanie się jest tu tak silne, że nawet w sformułowaniu, iż u Michała Anioła ciała ,przeniknięte” są treściami duszy, tkwiło dla Simmla zbyt dużo dualizmu. Przy innej okazji osiągniętą przez włoskiego artystę równowagę elementów Simmel zestawiał z poezją Johanna Wolfganga Goethego, w której znaczenie słowa i jego brzmienie stanowią doskonałość dzięki temu, że każdy z osobna reprezentuje najwyższy poziom: „W liryce Goethego odnajdziemy tę samą równowagę elementów co w rzeźbach Michała Anioła"18.

Jeśli malarzom odrodzenia, a później Rembrandtowi ${ }^{19}$ chodziło - używając uzasadnianej i szerzej stosowanej gdzie indziej Simmlowskiej kategorii —o in-

17 Temu dziełu warto by poświęcić więcej uwagi, gdyż znacząca zmienność owych podstawowych idei nie tyle ilustrowana, ile odczytywana była z przemian kierunków artystycznych: naturalizmu, impresjonizmu i ekspresjonizmu. W niektórych międzywojennych, także polskich, analizach tego ostatniego znalazły się zatem odwołania do Konfliktu kultury nowoczesnej Simmla — zob. np. S. Kasztelowicz, Tragicy doby bez ksztattu, Warszawa 1933. Z nowszych opracowań zob. O. Schwerdt, Geld und Unsinn. Georg Simmel und der Dadaismus Eine systematische Studie zu relativistischer Philosophie und Kunst, Leipzig 2012.

18 G. Simmel, Sztuka Rodina i motyw ruchu w rzeźbie, [w:] idem, Most i drzwi, przeł. M. Łukasiewicz, Warszawa 2006, s. 224. Warto w tym miejscu nadmienić, że jest to artykuł z 1909 roku.

${ }^{19}$ Simmel dodawał w tym momencie, że u tego artysty los człowieka przedstawiany jest w formie absolutnie jedynej indywidualności. Jak wiadomo, badacz włączył się do toczonej w Niemczech na przełomie XIX i XX stulecia żywej i wielowątkowej dyskusji o tym malarzu, a najbardziej reprezentatywna jest jego ponaddwustronicowe dzieło Rembrandt. Ein kunstphilosophischer Versuch (Leipzig 1916; polski przekład jego fragmentów zamieszczony został w poświęconym Simmlowi numerze „Filozofii i Sztuki” 27, 2005). Najwięcej odniesień do Michała Anioła znajduje się 
dywidualizm niepowtarzalności, to Michałowi Aniołowi — o to, co ponadindywidualne, to znaczy: ukazując osobową głębię postaci, eksponował on obiektywność ludzkiego losu. Przy tym, jak opisywał to Simmel, odróżniając styl germański od klasycznego, o ile w wypadku dzieł Rembrandta piękno wydaje się zewnętrznym dodatkiem do wypływającego z wewnętrznego źródła życia, o tyle dla artystów renesansowych — podobnie jak w epoce antycznej — było ono wartością podstawową. Obowiązywało to zarówno dla łączącego piękno ze szczęśliwą harmonią Giorgionego, jak i dla Michała Anioła ujmującego je z "tragiczną gwałtownością"20. Ostateczną zatem podstawą pewnego stypizowania bohaterów dzieł tego ostatniego twórcy jest to, że zostaje w nich odzwierciedlona „wszechjednia życia”. Dynamiczność przedstawianych postaci była rozwiązaniem sprzeczności między nieusuwalnym jego zróżnicowaniem a jednością. Dlatego Simmel tak wiele miejsca poświęcił kwestii ruchu, w którego czasowym przebiegu ujawnia się jedność duszy i ciała, substancji i procesu. W związku z tym dodawał, że Rafael ujmował człowieka poza czasem, jako byt w spoczynku, podczas gdy Buonarroti tak ściśle zespalał daną postać z konkretnym ruchem, że powstawało wrażenie jej stabilności $^{21}$. Autor Zur Philosophie der Kunst interpretował to jako dążenie do nadania

w drugim rozdziale tej książki, zatytułowanym Die Individualisierung und das Allgemeine, zwłaszcza przy omawianiu kwestii doskonałości (Vollkommenheit), losu ludzkiego i po heraklitejsku rozumianego kosmosu. Problematykę indywidualności u artystów renesansowych i późniejszych Simmel podniósł też w artykule Fragmenty filozofii sztuki (Bruchstücke aus einer Philosophie der Kunst, 1916; polski przekład w: idem, Most $i$ drzwi, s. 307-318). Simmlowskiej interpretacji Rembrandta poświęcono sporo uwagi — zob. np. E. Jain, Das Rembrandt-Bild bei Georg Simmel, „Zeitschrift. für Ästhetik und allgemeine Kunstwissenschaft" 33, 1988, s. 259-269; A. Kölb, Das Leben der Form: Georg Simmels kunstphilosophischer Versuch über Rembrandt, Wien 1998; A. Wauschkuhn, Georg Simmels Rembrandt-Bild. Ein lebensphilosophischer Beitrag zur Rembrandtrezeption in 20. Jahrhundert, Worms 2002; U. Kösser, Simmels „, Rembrandt”, „Simmel Studies” 2003, nr 2, s. 439-483. Agnieszka R. Rodriguez (Nieuchwytny obraz Rembrandta: Georga Simmla filozoficzna próba interpretacji „oeuvre” holenderskiego mistrza) w „Rembrandtowskim” monograficznym numerze „Rocznika Historii Sztuki” (33, 2008, s. 247-258) wyraziła opinię, że wokół tego twórcy koncentrowała się Simmlowska myśl o sztuce. Sporo w tym racji, choć podobnie powiedzieć można o Stefanie Georgem, Goethem i Michale Aniele. Horyzonty problemowe porównywania tego ostatniego z holenderskim malarzem zawiera w sobie konstatacja, której uzasadnienie stanowią także poglądy Simmla: „Michał Anioł i Rembrandt stoją u wrót nowoczesności” — R. Kasperowicz, Zweite, ideale Schöpfung. Sztuka w myśleniu historycznym Jacoba Burckhardta, Lublin 2004, s. 310.

${ }^{20}$ Zob. G. Simmel, Germanischer und klassich-romanischer Stil, „Der Tag” 2.03.1918, Abendausgabe. Illustrierter Teil, nr 52. W jego genezie germańskiego indywidualizmu zwraca uwagę wskazanie na protestanckie subiektywne rozumienie religijności i tego artystyczne artykulacje szczególnie u Rembrandta, dla którego indywidualny człowiek w swej codzienności stał się przedmiotem sztuki, a od „przedstawienia tego, co religijne” ważniejsze było „religijne przedstawienie”.

${ }^{21}$ W szerszym kontekście tę kwestię przedstawia Fritz Strich, Transpozycja pojęcia baroku, przeł. A. Węgrzecki, [w:] Współczesna teoria badań literackich za granica, red. H. Markiewicz, t. 2, Kraków 1976, s. 244-262. Z kolei o czasie u Simmla oraz wiążącym się z tym ujęciem śmierci i nieśmiertelności (to temat trzeciego rozdziału jego książki Lebensanschauung) zob. J.E. Jalbert, Time, Death, and History in Simmel and Heidegger, „Human Studies” 26, 2003, s. 259-283; A. Przyłęb- 
temu, co spełnia się w czasie, sensu przekraczającego ten czas. Ta charakterystyczna także dla Goethego umiejętność łączenia bezczasowej treści i procesu, w której się ona urzeczywistnia, wynikała z pełni twórczej osobowości. Istotnym kontekstem stosunkowo częstego w rozumowaniu i pisaniu Simmla zestawienia z sobą różnych, pochodzących z odmiennych czasów postaci była jego krytyka historyzmu. We wprowadzającym wykładzie o historii filozofii z roku 1904 przestrzegał, że znajomość rozwoju danej rzeczy nie oznacza uchwycenia jej istoty, a więc dzieła Fidiasza czy Michała Anioła trzeba ujmować również niehistorycznie, więcej nawet - dopiero to warunkuje osiągnięcie celu poznania historycznego ${ }^{22}$.

Formalna doskonałość dzieł Michała Anioła ma zatem pozwalać zrozumieć, że w ludzkim, zawsze fragmentarycznym, istnieniu pojawia się wyzwalające wyobrażenie życia jako takiego — a ono nie zna absolutnych przeciwieństw, na czele z tymi płciowymi, których Michał Anioł nie lekceważył; zdaniem autora Philosophische Kultur przez wszystkie jego wizualnie różnicowane postaci kobiece i męskie przemawiało to, co ogólnoludzkie. Szczególnie wyraźne było to dla niego w rzeźbach włoskiego artysty, a właściwy temu rodzajowi sztuki charakter przestrzenności — jej zamkniętość (w przeciwieństwie do malarstwa wciągającego widza we własną przestrzeń) — przydawał jeszcze powagi.

Zbieżne z tym wydają się pochodzące z początku lat trzydziestych XX wieku uwagi Johna Deweya:

Określenie sztuki jako zjednoczenia uniwersalnego z indywidualnym znajduje szczególne zastosowanie w stosunku do rzeźby [...]. Mojżesz Michała Anioła jest wysoce zindywidualizowany, nie ma w nim nic z uogólnienia ani nic epizodycznego, uniwersalizm bowiem jest czymś zupełnie różnym od uogólnienia. [...] Jednocześnie dzieło to mówi nam, przez zindywidualizowanie wartości i uczuć, o odwiecznym rozdźwięku między dążeniem a osiąganiem²3.

Formalnoartystyczna perfekcja na przykład figur na grobowcu Medyceuszy nie wyrażała dla Simmla subiektywnej doskonałości ani nie odsyłała do tego, co ponadludzkie. Ciało zostało tutaj bowiem potraktowane jako pole walki ludzkiej woli z przeciwstawiającymi się jej siłami fizycznymi i społecznymi; walki, w której dusza odnajduje potwierdzenie swej mocy. Choć o wierszach Buonarrotiego, które dotyczyły jego zmagań z rzeźbiarską materią ${ }^{24}$, Simmel pisał już wcześniej, teraz uogólniając, dodawał, że bez pokonywania oporu marmuru ${ }^{25}$ ludzka wol-

ski, Lis zimowa pora: Heidegger, Simmel i czas, [w:] idem, Duch czy życie? Studia i szkice z filozofii niemieckiej, Poznań 2011, s. 185-199. Potraktowanie w obu tych tekstach jako punktu odniesienia filozofii autora Bycia i czasu zawęża jednak analizę Simmlowskiej koncepcji czasu.

22 Zob. G. Simmel, Über Geschichte der Philosophie, [w:] Georg Simmel in Wien, red. D. Frisby, Wien 2000, s. 154.

23 J. Dewey, Sztuka jako doświadczenie, przeł. A. Potocki, Wrocław 1975, s. 286.

24 O samoświadomości artystycznej Michała Anioła zob. M.K. Siwiec, Twórca a myśl estetyczna Michała Anioła Buonarrotiego, „Filo-Sofija” 2007, nr 1, s. 35-59.

${ }^{25}$ Spośród polskich myślicieli początku XX wieku ponownie przypomnieć można Sobeskiego, bardzo dobrze zorientowanego w myśli niemieckiej, w którego zbiorze Interludia (Kraków-Warsza- 
ność popadłaby w pustkę. Bardzo przy tym znamienne jest, że sposób ujmowania przez niego dzieł sztuki zabezpieczał go przed zarzutem estetycznego formalizmu. W jego późnej twórczości ważniejszą rolę od formy zaczynała odgrywać kategoria formowania, czego najpełniejszym świadectwem jest rozprawa Die historische Formung z 1917 roku, w której wspomniane pojecie pozwalało mu opisać teoretycznie, jak to, co przeżyte, staje się treścią zdania historiograficznego ${ }^{26}$. Analizę przypominającego się $\mathrm{w}$ tym momencie jego stwierdzenia, że wbrew potocznym poglądom sztuka nie jest „wehikułem historii”, a ta druga stanowi „przedformę" pierwszej, z konieczności trzeba jednak pominąć.

Simmel pokazywał zatem, jak najistotniejsza - czy to dla Michała Anioła, czy to dla Rembrandta — problematyka wyraża się w zewnętrznej i wewnętrznej formie ich sztuki. W jego artykule z 1901 roku, poświęconym innemu i szerszemu zagadnieniu, znalazła się taka uwaga:

U Michała Anioła wszystkie postacie zmagają się z naciskiem, straszliwy ciężar ciągnie je w dół, toteż muszą użyć namiętnej siły, aby nie ulec, walka duszy, która chce się uwolnić, z elementarnym ciążeniem naturalnego bytu, symbolizującym zarazem głuchy tragizm wewnętrznych obciążeń - ta walka nieruchomieje w momencie kulminacji obu przeciwstawnych dążności. Gdy ta równowaga, z niepojętym kunsztem uchwycona w kolejnych dziełach, poczyna się w późniejszym rozwoju chwiać, gdy duchowa wolność i impulsywność pełniej dochodzą do głosu, zdawałoby się wskutek zwykłego pominięcia siły ciężkości, styl Michała Anioła przechyla się ku barokowi ${ }^{27}$.

wa 1912) znalazł się szkic Myśl a marmur (s. 110-143). Ponadto przeprowadzone w swej poprzedniej książce rozumowanie badacz podsumował następująco: „Więc Dawid nie jest skamieniałym człowiekiem — jeno ożywionym marmurem" (idem, Przędziwo Arachny, s. 41).

26 Jest ona reprezentatywna dla ostatniej fazy rozwoju Simmlowskiej teorii poznania historycznego, ale Viktor Lau (Erzählen und Verstehen: historische Perspektiven der Hermeneutik, Würzburg 1999, przypis na s. 493) słusznie zwraca uwagę, że pojęcie formowania pojawiło się już w jego pracach o Michale Aniele, Rodinie i Rembrandcie. Jakie były tego konsekwencje dla ujęcia problematyki sztuki, pokazują słowa podążającego w wielu sprawach za Simmlem, swoim nauczycielem, młodego Györgya Lukácsa: „Powtarzam: esteta pojęcia formy stosuje do życia; kultura estetyczna jest kształtowaniem ducha. Nie zdobieniem, lecz kształtowaniem [...]; nie wypełnianiem formy, lecz kształtowaniem; nie rezultatem, ale drogą bez końca, na której ukształtowane okruchy życia znaczą postęp" (idem, Kultura estetyczna, przeł. E. Cygielska, [w:] idem, Pisma krytyczno-teoretyczne 1908-1932, Warszawa 1994, s. 161). Temu sformułowaniu z 1913 roku towarzyszyła krytyka subiektywizmu i relatywizmu Lebensphilosophie, co wiązało się u Lukácsa z badaniami nad heglizmem i marksizmem. Bardzo ciekawy materiał do analizy stanowią wydane przed paroma laty jego Notizen zu Georg Simmels Vorlesungen, 1906/07 und zur „,Kunstsoziologie”, ca. 1909, Berlin 2011. Warto również dodać, że dla Karla Mannheima (1918), który podkreślał „przedustawną harmonię” między formą eseju a pisarskim talentem Simmla, jego praca o Michale Aniele dowodziła, jak doskonale niemiecki filozof w tym, co typowe czy indywidualne, potrafił dostrzec to, co symboliczne, a ostatecznie „całość życia” (idem, Georg Simmel als Philosoph, [w:] Georg Lukács, Karl Mannheim und der Sonntagskreis, red. E. Karadi, E. Vezér, Frankfurt am Main 1985, s. 153).

27 G. Simmel, Most i drzwi, s. 88-89. Słowa te pochodzą z rozprawki Estetyka ciężkości z roku 1901, a zostały przytoczone z jej nowego przekładu. Jako jedno z pierwszych polskich thumaczeń prac Simmla (podpisane tylko inicjałami S.G.) ukazała się ona w wydawanym przez Cezarego Jellenta 
Myśl ta została rozwinięta w późniejszej o dziesięć lat rozprawie w „Logosie”, w której dodano, że włoskiemu artyście chodziło o ujęcie wzajemnego przenikania się losu i wolności, o świadomość walki bez nadziei na zwycięstwo, gdyż nie widział on podstaw do obwieszczania zwycięstwa duszy. Simmel zgadzał się, że rzeźby staroegipskie, antyczne czy barokowe oddawały smutek ${ }^{28}$, ale tragiczność (die Tragik) pełny wyraz zyskała dopiero u Michała Anioła. Przeciwstawiając jego nieukończone dzieła Narodzinom Wenus Botticellego, filozof dowodził, że tragiczność rzeźbiarskich figur Michała Anioła wyraża się w tym, że spokój bytu zostaje zburzony w stawaniu się, a forma w nieskończonym rozrywaniu formy.

Jak było przypomniane, rok po rozprawie Michelangelo na łamach tego samego pisma Simmel opublikował pracę Der Begriff und Tragödie der Kultur, w której pełniej i w bardziej ogólnym wymiarze przedstawił swe rozumnie tragizmu. Chociaż jeszcze parę lat później (w 1918 roku), w kontekście jeszcze szerszej problematyki, filozof stwierdzał, iż „tragizm ducha w ogóle” polega na tym, że

życie rani się często o kształty, które wyrzuciło ze swego wnętrza jako sztywnie obiektywne, ponieważ nie znajduje do nich dostępu. Jego subiektywna postać nie potrafi sprostać wymaganiom, które samo w tych kształtach rozwinęło. Jest to bolesny dowód, że chodzi o prawdziwą obiektywność w każdym możliwym do wydobycia z niej sensie, i w żadnym razie o jej psychologizację ${ }^{29}$.

Jakkolwiek badacze spierają się o sens teoretyczny i filozoficzny tego fragmentu koncepcji Simmla czy nawet zastosowaną przez niego terminologię, to można zgodzić się, że tragedia była dla niego immanencją i jako ciągły ruch kulturalnego poróżniania - mimo pewnego tonu w jego pracach z początkowego

piśmie „Ateneum” (Jerzy Simmel, Estetyka ciężkości, „Ateneum” 2, 1904, nr 4, z. X-XI-XII, s. 99104). Rozprawka ta znamienna jest jeszcze z co najmniej czterech powodów. Po pierwsze, związane z ciążeniem prawa Newtona Simmel przywoływał, omawiając problem obiektywności wytworów kulturalnych; po drugie, dostrzec tu można źródła Kantowskie, a ujmując szerzej — traktowanie natury jako stawiającej opór ludzkiej wolności; po trzecie, wykorzystana została tutaj Schillerowsko-Goetheańska koncepcja „pięknej duszy”, która - po czwarte - została skonfrontowana z po nietzscheańsku rozumianą godnością. Nawiązując do tytułu artykułu, od którego rozpoczynają się zazwyczaj wszystkie analizy zagadnienia estetyzacji u Simmla, a mianowicie do Estetyki socjologicznej, można uznać, że Estetyka ciężkości reprezentuje estetykę etyczną.

${ }^{28}$ Warto przy tym uzupełnić, że dla autora Filozofii pieniadza dopiero sztuka chrześcijańska wyraziła w obrazowym języku cierpienie, które jest immanentne, a nie zewnętrzne wobec życia. Dlatego Simmel uznawał, że antyk znał smutek, który jest jednakże uogólnionym refleksem cierpienia. Z kolei twierdzeniu o niechęci chrześcijaństwa do sztuki z racji potępienia tego, co zmysłowe, przeciwstawiał pogląd, że bardziej wypływa ona z przekonania duszy o wzięciu w posiadanie tego, co znajduje się poza zmysłowym światem. Artykuł Simmla Die Christentum und die Kunst (1907) szeroko omówiony został przez Dominikę Motak, Między transcendencją a immanencją. Religia w myśli Georga Simmla, Kraków 2013, s. 105-107.

${ }_{29}$ G. Simmel, Filozofia życia. Cztery rozdziaty metafizyczne, przeł. M. Tokarzewska, Warszawa 2007, s. 89. 
okresu I wojny światowej — wykluczała jakąkolwiek apokalipsę ${ }^{30} \mathrm{i}-$ można dodać - eschatologię.

Buonarroti fascynował niemieckiego filozofa, ponieważ w swej twórczości artystycznej doprowadzał do jedności to, co dla myśli było nieusuwalnym przeciwieństwem, i właśnie dzięki temu konflikt i walka ukazały swój metafizyczny wymiar. Nawiązując do założeń filozoficznych, które przedstawiał w innych swych pracach, Simmel odnajdował zgodność między metafizyką Heraklita a sztuką Michała Anioła. W tym jednak stopniu, w jakim dzieła tego ostatniego poprzez wysoki poziom osiągnęły estetyczną doskonałość i rozwiązanie problemu sztuki w ogóle, a także potęgowały tęsknotę za tym, czego nie udało się doprowadzić do zamkniętej jedność bytu.

Tak rzecz stawiając, autor Zur Philosophie der Kunst podejmował problem już nie dzieł, ale sensu twórczości i życia Michała Anioła, a dokładniej ujmując i oddalając wszelki biografizm - jego losu ${ }^{31}$. Renesansowy tegoż charakter wyrażał się w tym, że średniowieczna, gotycka tęsknota religijna zwróciła się w stronę ziemskiego świata. Religia obiecywała osiągnięcie tego, co nieskończone, za pomocą skończonych wysiłków; albo inaczej - upragnioną nieskończoność w skończonej dali. Odrodzenie zmieniło kierunek chrześcijańskiego transcendentowania i ludzkiemu życiu przypisało cel, który nie jest możliwy do osiągnięcia wewnątrz tego, co skończone, albo inaczej - upragnioną skończoność w nieskończonej dali.

Postaci z dzieł Michała Anioła były dla Simmla ,ponadempiryczne”, ale nie stały ponad tym, co ziemskie; los tego zaś artysty zasługiwał na miano tragicznego, gdyż kierując się zawsze ku nieskończoności, działał on jednak w czasie, który się od niej odwrócił; szukał więc ukojenia w formowaniu tego, co naturalne. Artystyczne tego efekty były doskonałe, ale niezaspokojona tęsknota pozostawała. Dlatego w postaciach włoskiego rzeźbiarza Simmel dostrzegał sprzeczność między jednoczesnym byciem doskonałym i nieszczęśliwym. $Z$ tej racji za wyjątek uznawał Pietę Rondanini, w której to, co cielesne, zdawało się wyrzekać swoich roszczeń. Odrzucenie podstawowego dla Michała Anioła napięcia między transcendentną tęsknotą a zawsze ułomnym jej materialnym wyrazem zaowoco-

${ }^{30}$ Zob. J. Jacob, Tragische Fülle. Kultur, Erinnerung und Apokalypse bei Georg Simmel, [w:] Apokalypse und Erinnerung in der deutsch-jüdischen Kultur des frühen 20. Jahrhunderts, red. J. Brokoff, Göttingen 2002, s. 75-98. Nawiązując do znanego rozróżnienia Ernsta Cassirera, autor przywołanego artykułu uznał, że u Simmla mamy do czynienia z przejściem od substancjalnego do funkcjonalnego pojmowania tragiczności. Z tym też związał ścisły formalizm oraz abstrakcyjny charakter Simmlowskiej krytyki kultury.

${ }^{31}$ Co oznacza ta kategoria, Simmel przedstawił w Das Problem des Schicksals („Die Geistesswissenschaften” 1, 1913, z. 5, s. 112-115), a potem w wydzielonej części trzeciego rozdziału Lebensanschauung (1918). Polski przekład pierwszego tekstu znajduje się w książce G. Simmel, Filozofia kultury. Wybór esejów, przeł. W. Kunicki, Kraków 2007, s. 155-161; drugiego - w idem, Filozofia życia..., s. 108-113. 
wało jedynie negatywnym zbawieniem. Wedle Simmla było to bliskie nirwanie, a jeśli oznacza ona powstrzymanie się od walki, właśnie to wyjątkowe w dorobku Michała Anioła dzieło najmocniej unaoczniało doświadczaną przez niego tragiczność — niemożność osiągnięcia zbawienia poprzez twórczość skoncentrowaną na sztuce i pięknie. Znajdowało to potwierdzenie także w jego wierszach, czego Simmel dowodził, nawiązując wyraźnie do swej ich dawnej analizy. Podobnie też powrócił do zagadnienia miłości, uznając, że z nią, identycznie jak ze sztuką, Michał Anioł wiązał nadzieję na osiągnięcie Mehr-als-iridisches i w obu przypadkach uświadomił sobie tego zawodność.

Tematyka ta została jednak teraz pogłębiona wnioskami, które Simmel uzasadnił w swych obszernych artykułach Weibliche Kultur (1902) i Das Relative und das Absolute im Geschlechter-Problem $(1911)^{32}$. W ponownym ujęciu analizowanej już w 1889 roku problematyki pojawiły się odniesienia do Rubensa i Tycjana - malarzy równie „erotycznych”, ale skupionych na poszczególnym uczuciu, a nie losie ku miłości prowadzącym bądź ją rozszerzającym. Simmel od razu jednak zastrzegał, że Michał Anioł nie pojmował człowieka abstrakcyjnie (jak w antycznej rzeźbie greckiej) ani nie sprowadzał świata do ,ja”. Jego postaci wyrażają bowiem wewnętrzną postawę wobec życia, opartą na przeświadczeniu, że to los świata i życia stanowi źródło oraz sens osobistego przeznaczenia. U Fra Angelico piekło, którego należy się lękać, było na zewnątrz człowieka, podczas gdy Michał Anioł także obawiał się mąk piekielnych, ale było to jedynie historycznie określoną projekcją odczuwania fragmentaryczności ludzkiego istnienia. Nie miało to zatem nic wspólnego ze skupianiem się na sobie, a ujmowało obiektywny sens egzystencji. Simmel dopatrzył się tu „personalizmu” w takim rozumieniu, w jakim określenie to można odnieść również do filozofii Friedricha Nietzschego. Dzieła Michała Anioła ukazywały tragiczność w czystej postaci, a on sam okazywał się „osobowością tragiczną”. Z całą mocą objawił się tutaj jeden z „nieskończonych problemów ludzkości", to jest kształtowania tego, co absolutne, w tym, co skończone, znalezienia zbawienia w samym życiu. Dla autora Filozofii pieniadza zarówno Goethe (zwłaszcza w Fauście), jak i Nietzsche podjęli tę samą kwestię, ale to Michał Anioł w naocznej formie sztuki ukazał, jak jej rozwiązywanie nadaje życiu jedność i zarazem wyraża jego sprzeczności. Dotarł w ten sposób do granic, które zaczęły się teraz domagać przekroczenia.

Rozważania o twórcy fresków w Kaplicy Sykstyńskiej Simmel zakończył refleksją, że rozstrzygające o ludzkości jest to, gdzie upatruje ona - wykluczając gwarancje dogmatycznego objawienia — szanse pogodzenia swej skończoności i potrzeby absolutu, gdzie znajduje nieznające tej sprzeczności „królestwo”. O ile zatem formułę losu Michała Anioła można zawrzeć w domaganiu się od pełni

32 Weszły one w skład książki Philosophische Kultur (Leipzig 1911), w której, co wypada przypomnieć, ukazała się też praca o Michale Aniele z „Logosu” i rozprawa Der Begriff und die Tragödie der Kultur. 
skończoności pełni nieskończoności, o tyle jego w najwyższym stopniu naznaczone - w wyłożonym sensie — tragicznością dzieło i życie miało pokazywać, że ludzkość nie znalazła jeszcze takiego „trzeciego królestwa”. Często pojawiającą się u Simmla i skłaniającą do daleko idących wniosków figurę tego, co trzecie, dostrzega wielu badaczy jego koncepcji. W odniesieniu do stosunkowo specjalistycznego problemu filozofii sztuk plastycznych badacz wskazywał, że w dwuwymiarowej płaszczyźnie trzeci wymiar pojawia się za sprawą artystycznego organizowania tego, co widzialne, a dzięki temu osiągnięte zostaje coś więcej (Mehr). Dodatkowo podczas gdy przyrodoznawstwo wszelkie jakości sprowadzana do ilości (Quantitätausdrücke), sztukę we wszelkich bytowych ilościach interesują wartości jakościowe (Qualitätswert) ${ }^{33}$.

O ile w artykule w „Logosie” cechy i tendencje twórczości Michała Anioła nabierały wyrazistości na tle sztuki ją poprzedzającej i jej współczesnej, to podobnie — choć w mniejszym wymiarze — działo się tak, gdy Simmel w 1902 roku konfrontował ją z dziełami Rodina (skądinąd w wąskim zakresie czynił tak również Sobeski), którego twórczością żywo się interesował, stwierdzając przy tym dość apodyktycznie: „historia rzeźby kończy się na Michale Aniele”34. Przeciwstawiając sobie dzieła obu tych artystów, Simmel wskazywał na historyczną zmianę w sposobie przedstawienia w sztuce pełnej napięć dynamiki ciała. Co więcej, niepokój stawania się, niestałość formy, ,artystyczna bezczasowość czystego ruchu”, które dostrzegał w rzeźbach Rodina, oddawały charakter nowoczesności ${ }^{35}$. Pokazywało to wyraźnie zgodność, współbrzmienie między Simmlowską socjologią i filozofią sztuki (przynajmniej w odniesieniu do opisu nowoczesności).

W pracy Rodin - mit einer Vorbemerkung über Meunier (1911) Simmel dowodził, że o ile zharmonizowane postaci Michała Anioła mają charakter abstrakcyjnej struktury plastycznej, o tyle francuski rzeźbiarz, jeszcze mocniej akcentując ruch, sprawił, że ciało stało się ożywione (już nie Körper, ale Leib). W ogólniejszych kategoriach oznaczało to, że życie osiągnęło swą formę, a opisując to jeszcze od innej strony - o ile u włoskiego artysty koincydencja cielesnego bycia i ruchu ostatecznie odsyłała do renesansowego ideału duszy, o tyle podobnie u Rodina dusza jest ogniskiem tego, co cielesne, i tego, co widzialne, lecz jest to dusza nowoczesna - od renesansowej o wiele bardziej zmienna zarówno w swoich nastrojach, jak i losie. Rozwibrowanie tej drugiej łączy się z tym, że jej przeznacze-

33 Zob. G. Simmel, Über die dritte Dimension in der Kunst, ,Zeitschrift für Ästhetik und Allgemeine Kunstwissenschaft" 1906, z. 1, s. 69.

34 G. Simmel, Most $i$ drzwi, s. 94. Zdanie to pochodzi z rozprawy Rzeźby Rodina i duchowe tendencje współczesności z 1902 roku. Zob też idem, Die Kunst Rodins und das Bewegungsmotiv in das Plastik, „Nord und Süd” 1909, z. 386, s. 189-196.

35 Zagadnienia te analizuje Dominik Brabant, ,, Moderner Heraklitismus”. Georg Simmels Arbeit an einer Philosophie der Kunst in Bewegung und Kunstdiskurse in Berlin um 1900, „LMU Publikationen/Geschichts- und Kunstwissenschaften” 2008, nr 28, http://epub.ub.uni-muenchen.de (dostęp: 21 września 2018). 
nie nie jest tak definitywnie jak u Michała Anioła określone, gdyż uwielbia ona, jak to zwięźle Simmel ujmował, „drogę bez celu” i ,cele bez dróg”. Jak zauważył jeden z badaczy, tę różnicę dałoby się też ująć, wykorzystując przywoływaną już Cassirerowską opozycję substancjalności i funkcjonalności. Z kolei przypomniane już zestawienia Buonarrotiego z Goethem uzupełnić w tym momencie można odniesieniem twórczości Rodina do wierszy Georgego ${ }^{36}$, których dźwiękowa uroda zachwycała Simmla nie tylko swą zewnętrzną zmysłowością, ale jako ich wewnętrzny punkt wyjścia. W 1911 roku tak to ujmował: „Jak Stephan George wyraził w liryce płynną, muzyczną dynamikę nowoczesnej duszy, tak Rodin wynajdując styl współczesny, uformował ją w kamieniu"37. Filozoficzne przemyślenia $\mathrm{i}$ artystyczne dokonania zgodnie zatem definiowały nowoczesność poprzez ruch czasu i zmienność.

Charakteryzując ten fragment koncepcji Simmla, Matthias Junge dostrzegł, że ujęcie nowoczesności jako ruchu pozwalało zintegrować formę i treść zjawisk, działanie i strukturę, a trwały ład społeczny traktować jedynie jako przypadek graniczny jego nieustannej zmienności. Wynikał z tego ponadto obraz rozwoju nowoczesności prowadzący od rozwoju pierwotnego dualizmu poprzez odrzucenie możliwości zsyntetyzowania jego biegunów do ich dynamicznego wzajemnego związania $^{38}$. Trudno jednak zapomnieć, że ten formalny schemat Simmel stosował w odniesieniu do bardzo wielu zjawisk, a w znacznej mierze jest on adaptacją jednej z podstawowych zasad Spencerowskiego ewolucjonizmu.

O ile wcześniej — z pewnością nazbyt skrótowo — wskazane zostały przejścia między Simmlowską refleksją nad przemianami społecznymi a jego rozważaniami o sztuce, to równie wyraźne można odnaleźć między tymi ostatnimi a jego poglądami dotyczącymi moralności i religii, a warto przypomnieć, że Siegfried Kracauer uznawał Simmla wręcz za myśliciela o religijnych instynktach i potrze-

36 Siłą rzeczy pełniejsza charakterystyka Simmlowskiej refleksji o sztuce wymagałaby uwzględnienia jego prac dotyczących literatury, a szczególnie Goethego i Georgego, oraz aktorstwa (zob. P. Pilgram, Der Schauspieler als Symbol moderner Kultur bei Simmel, Kracauer und Plessner, Nürnberg 2010), choć te ostatnie wydają się dla omawianych tutaj kwestii mniej interesujące. Z nowszych opracowań zob. D. Burdorf, Formdenken als Theorie des lyrischen Kunstwerks: Stefan George und Georg Simmel, [w:] idem, Poetik der Form. Eine Begriffs- und Problemgeschichte. Stuttgart 2001, s. 436-441; M. Tokarzewska, Der feste Grund des Unberechenbaren: Georg Simmel zwischen Soziologie und Literatur, Opladen 2010; a w szerszej perspektywie U. Hebekus, Der Wille zur Form. Politischer Ästhetizismus bei Georg Simmel, Ernst H. Kantorowicz und Alfred Rosenberg, [w:] Die Souveränität der Literatur. Zum Totalitären der klassischen Moderne 1900-1933, red. U. Hebekus, I. Stöckmann, München 2008, s. 45-75.

37 G. Simmel, Die kulturgeschichtliche Bedeutng Rodins, [w:] Georg Simmel in Wien, s. 214-215.

38 Zob. podrozdział „,Rodin” und „Michelangelo”: Simmels Konzeption der Moderne w książce Matthiasa Jungego, Georg Simmel kompakt, Bielefeld 2009, s. 52-54. Uważnej lekturze polecić warto też wstęp Anny Zeidler-Janiszewskiej (Nowoczesność jako postawa i zadanie) do wyboru esejów Simmla Most i drzwi (s. VII-XVIII). 
bach $^{39}$. W artykule Rzeźby Rodina i duchowe tendencje wspótczesności Simmel stwierdzał bowiem, że

sferę życia wewnętrznego i zewnętrznego przenika tęsknota za tym, co można nazwać prawem indywidualnym, a co jednałoby życie osobiste, nie podlegające uogólnieniom, z godnością, szerokim zasięgiem i określonością prawa ${ }^{40}$.

W tym cytacie szczególna rola przypada pojęciu ,prawo indywidualne”. Opracowane i rozbudowane przez tego myśliciela zostało ono przede wszystkim odniesione do problematyki etycznej, streszczając w sobie ostatnie jego rozstrzygnięcia w tej filozoficznej subdyscyplinie. Organizowanie zgodnie z prawem indywidualnym własnej egzystencji oznaczało zatem domaganie się takiego pojednania bytu i powinności, rzeczywistości i ideału, procesu i formy, które dokonuje się na płaszczyźnie życia. Najprawdopodobniej tę kategorię Simmel zaczerpnął z pism Friedricha Schleiermachera, lecz w swoich pracach z filozofii religii jej nie stosował, albowiem w nich temu, co obejmowała ona jako zasada etyczna, odpowiadała idea zbawienia. Jego chrześcijańskie ujmowanie poddawał on znacznej modyfikacji, ale podobnie chodziło o wyzwolenie tego, co indywidualne, a to oznaczało odrzucenie opozycji subiektywnego i obiektywnego; albo - wyrażając się inaczej — osiągnięcie absolutnego znaczenia przez to, co czasowe.

W przypominanym już artykule Das Christentum und die Kunst Simmel podkreślał, że podstawowe podobieństwo między sztuką a religią, z których każda jest $\mathrm{w}$ sobie i dla siebie, zawiera się $\mathrm{w}$ tym, że obie dzięki ujmowaniu swego przedmiotu $\mathrm{w}$ jak największym dystansie najbardziej zbliżają do niego. $\mathrm{W}$ obu dziedzinach w grę wchodzi takie negowanie rzeczywistości, które ostatecznie przekształca się w pozytywny stosunek do niej. Dzieło sztuki oferuje uwolnienie od życiowego zaplątania, ale przecież w owo życie wkracza, a to, co wnosi, jest formą samego życia. W takim rozumowaniu późnego Simmla życie jako takie stawało się ostateczną podstawą i zasadą wszystkich zjawisk, w tym sztuki.

W innym miejscu, choć w formie przypuszczenia, filozof wyraził opinię, że jakkolwiek zostało wytworzone przez człowieka, dzieło sztuki charakteryzuje się

39 Zob. S. Kracauer, Georg Simmel, „Logos” 9, 1920-1921, s. 307-338. Spośród prac poświęconych Simmlowskim poglądom na temat religii — z uwagi na rozważany tutaj temat — szczególnie cenna jest książka Volkharda Krecha Georg Simmels Religionsphilosophie (Tübingen 1998), w której analizując je w warstwie psychologicznej, socjologicznej, kulturoznawczej i filozofii życia — co jest rozróżnieniem jednocześnie systematycznym i chronologicznym — badacz podjął oczywiście też problem religijności i sztuki (s. 149-151). Zob. też wieńczący rozważania Ute Faath (Mehr-als-Kunst. Zur Kunstphilosophie Georg Simmels, Würzburg 1998) rozdział Philosophie, Kunst oder Religion: Erkenntnis contra Erlösung (s. 233-240).

${ }^{40}$ G. Simmel, Most $i$ drzwi, s. 96. Zob. też H. Niehues-Pröbsting, Das ,,individuelle Gesetz” in der Kunst. Georg Simmels Ästhetik in der Lebensphilosophie, [w:] Kunst gibt zu denken, red. U. Franke et al., Münster 1981, s. 100-114, gdzie ta tak istotna dla Simmla kategoria wywiedziona została - mimo wszystko - z dziedzictwa estetyki idealistycznej; oraz F. Vandenberghe, La loi individuelle. Une éthique nietzschéo-bergsonienne, „Simmel Studies” 2000, nr 2, s. 169-178. 
obiektywnością, której rzeczywistością jest idea i zasada, oraz — odwrotnie której ideą i zasadą jest rzeczywistość, co pokazuje, że wszelkie targające życiem i myśleniem dualizmy wypływają ostatecznie z naszej „,istotowej głębi”. W tym też sensie dzieło sztuki niesie w sobie ,symbol ostatecznej tajemnicy nas samych"41, a nowoczesna dusza potrzebuje autarkicznej sztuki jako symbolu swej autonomii. „Zbawienia dzięki sztuce” pozwalają doznać, zdaniem Simmla, jej największe dzieła, z których każde będąc czymś dla siebie, staje się zarazem czymś dla nas. Ta pierwsza cecha, to jest charakter zamkniętej całości, charakteryzuje wybitne dzieła sztuki. Ich styl jest wyrazem indywidualnych właściwości artysty, a z racji tego, że osiągnęły one poziom obiektywności, dziełu sztuki przysługuje druga ze wskazanych cech. Dlatego Simmel uznawał, że wobec między innymi Michała Anioła pytanie o styl epoki traci estetyczną ważność, a określenie „styl Michała Anioła" oznacza, że posługiwał się on takimi środkami wyrazu, iż w każdym jego poszczególnym dziele odczuwalna jest ogólność jego indywidualnego geniuszu. Zwięźle to ujmując, a Simmel odwoływał się w tym wypadku do uzusu językowego, czerpiący od Michała Anioła „mieli” jego styl — on sam był stylem ${ }^{42}$. Nieco inaczej tylko to wyrażając, Simmel podtrzymał tę opinię kilkanaście lat później w artykule Gestalter und Schöpfer („Der Tag” 10.02.1916, nr 74, Ausgabe A, Morgenausgabe, Illustrierter Teil, nr 34), przedstawiając Michała Anioła jako „najdoskonalszy typ twórcy”, którego „duch” przemawia we wszelkich jego dziełach. Można je rozpatrywać jako wyraz osobowości, ale pod warunkiem że odejdzie się od pojmowania psychologicznego ku traktowaniu jej jako idei lub prafenomenu.

Właściwości Simmlowskiego rozumienia sztuki, które zostało przedstawione w odniesieniu do filozofii religii, uwidaczniają się na tle innych ówczesnych koncepcji nowoczesności, na przykład Maxa Webera, z którym autora Filozofii pieniądza wiele łączyło, ale i od którego dużo go oddzielało. Siłą rzeczy nawet w tym, co wiąże się z odmiennościami ich opisów nowoczesności, ograniczyć się tutaj trzeba do ujęcia sztuki. Dla autora Etosu protestanckiego i ducha kapitali$z m u$ w nowoczesnym, „odczarowanym”, to znaczy pozbawionym jednoczącego czynnika, świecie, któremu piętno nadają procesy racjonalizacji, sztuka stanowi jednego z bogów, z których każdy wymaga pełnego dla siebie poświęcenia i wyraźnie odgranicza się od pozostałych. Skoro żaden z nich nie jest w stanie wystarczająco mocno uzasadnić swych roszczeń, pojawia się ryzyko oddania się „królestwu diabelskiego piękna”. Takiego wyrażenia Weber użył w słynnej rozprawie Nauka jako zawód i powołanie (1919), w której z punktu widzenia wymogów

41 Zob. G. Simmel, Die Gesetzmäßigkeit im Kunstwerk, „Logos” 3, 1917/1918, s. 223.

42 Zob. G. Simmel, Das Problem des Stiles, „Dekorative Kunst. Illustrierte Zeitschrift für Angewandte Kunst" 11, 1908, nr 16 s. 307-316; polski przekład w idem, Filozofia kultury..., s. 177-184. Prowadziło to ku egzystencjalistycznej koncepcji stylu, a takowa formułowana było w okresie międzywojennym, choć bardziej bezpośrednio odwoływała się do Heideggera. 
nowoczesności poddawał krytyce fascynację estetycznym przeżyciem, mogącą mieć jedynie intymny wymiar, ale w wymiarze społecznym oznaczającą powrót do stadium już minionego. Dla rozbudowującego Schillerowską metaforę Webera próby estetycznego ,zaczarowania świata” stanowiły zrozumiałą psychologicznie, ale błędną etycznie reakcję na dolegliwości nowoczesności. Ocena ta była osadzona w perspektywie historycznej, a zmiennej relacji sztuki od innych dziedzin życia kulturalnego wspomniany badacz poświęcił sporo uwagi. W liście do Aby Warburga dzielił się spostrzeżeniami o życiu artystycznym odrodzeniowej Florencji, w którym - podobnie jak w innych sferach — dawał o sobie znać brak wypracowania etyki zawodowej; wskazywał na oddziaływanie twórczości Rembrandta i purytanizmu na dzieje sztuki. Kiedy uwzględnia się całościowy zamysł Weberowskiej socjologii religii, zrozumiałe jest, dlaczego podjął problem miejsca i funkcji sztuki w procesie powstawania nowoczesnego świata. Ważne jest przy tym, że ze wskazaniem na autonomizowanie się sfery estetycznej łączyła się tu jej obrona przed radykalnymi jej krytykami, które ostatecznie wynikały z negacji samej nowoczesności, a zwłaszcza rozdzielenia rejonów podległych różnym „,bogom”43. W wykładzie Nauka jako zawód i powołanie Weber wszakże zdecydowanie oponował przeciw przedkładaniu sądów smaku nad etykę odpowiedzialności, a nowoczesną sztukę oskarżał o składanie obietnicy „,wewnątrzświatowego zbawienia" od codzienności.

Klaus Lichtblau, znawca twórczości zarówno Simmla, jak i Webera, bardzo przekonująco dowodzi, że u tego drugiego z negatywną oceną subiektywizujących i estetyzujących tendencji ówczesnej młodzieży łączyła się ogólniejsza polemika $\mathrm{z}$ tak wyraźnym na przełomie XIX i XX wieku w Niemczech kultem sztuki i hasłami powrotu do klasyki, które autor Gospodarki i społeczeństwa traktował jako konsekwencje mieszczańskiego wykształcenia ${ }^{44}$. Z opisu charakteru i dynamiki

43 Scott Lash, rozważając w 1994 roku o refleksyjności estetycznej, sformułował taki — godny przytoczenia głównie z uwagi na odniesienia do Simmla i Webera — wniosek: „Trudno ją uznać za coś nowego. Jej początki sięgają oczywiście estetyki Kanta z Krytyki władzy sądzenia; potem została rozwinięta przez Webera i Simmla w ich koncepcjach przebiegu życia i Persönlichkeit; spotykamy ją u Habermasa jako wymiar działania komunikacyjnego i dyskursu. Ma swoje miejsce w myśli Charlesa Taylora jako zasadnicze źródło nowoczesnego ja. Nierozerwalnie łączy się z hermeneutyką, co pokazał sam Taylor i o czym świadczy wnikliwa książka Wolfa Lepeniesa Trzy kultury, będąca w istocie intelektualną historią dwóch kultur — naukowej i literackiej — reprezentowanych, z jednej strony, przez scjentystyczną teorię społeczną, a z drugiej, przez hermeneutykę. Simmel, klasyczny teoretyk socjologii, w swoich późniejszych, hermeneutycznych analizach przyjmuje w gruncie rzeczy założenia natury estetycznej" - idem, Systemy eksperckie czy kontekstowa interpretacja. Kultura $i$ instytucje $w$ zdezorganizowanym kapitalizmie, przeł. J. Konieczny, [w:] Modernizacja refleksyjna, red. U. Beck, A. Giddens, S. Lash, Warszawa 2009, s. 270.

${ }^{44}$ K. Lichtblau, „Innerweltliche Erlösung vom Rationalen” oder „, Reich diabolischer Herrlichkeit"? Zum Verhältnis von Kunst und Religion bei Georg Simmel und Max Weber, [w:] Kunst und Religion. Studien zur Kultursoziologie und Kulturgeschichte, red. R Faber, V. Krech, Würzburg 1999, s. 51-78; zob. idem, Zum Stellenwert der ästhetisch-literarischen Moderne in den kultursoziologischen Gegenwartsanalysen von Georg Simmel und Max Weber, [w:] Konzepte der Moderne, 
nowoczesności wypływało dla Webera wskazanie etyczne, że należy „sprostać wymogom dnia". Stanowiło to nawiązanie do 30 i 31 aforyzmu Refleksji i maksym Goethego, w których spełnianie obowiązku uznane zostało za warunek poznania własnej wartości, a ów obowiązek to die Forderung des Tages. Niemiecki poeta istotniejszy okazywał się zatem ze względu na to, co miał do powiedzenia na temat zawodu i powołania, niż — jak było to u Simmla — jako ten, który jednał w sobie fakt i powinność, życie i sztukę. Wykorzystanie słów Goethego dla oddania idei etyki odpowiedzialności przy jednoczesnym wyrażeniu powątpiewania, czy życiu można nadać kształt dzieła sztuki i czy osobowość samego Goethego stanowiła urzeczywistnienie idei osobowości, uwidacznia, w czym Weber różnił się od Simmla w interpretacji twórcy Fausta, roli sztuki, charakteru nowoczesności, pojmowania tragiczności i koncepcji etycznej. Bez wątpienia Lichtblau ma rację, wskazując, że Simmel w większym stopniu nawiązywał do sposobu ujmowania roli sztuki ${ }^{45}$, który — mimo ewidentnych różnic — rozwijali Schiller i Schopenhauer, a ponadto rozważania o religii i sztuce łączył tak, że od opozycji względem doczesnego świata istotniejsze było reprezentowanie przezeń absolutu w tym, co indywidualne:

To specyficzne w e w n ą tr z ś w i a t o w e zbawienie od sprzeczności nowoczesnego życia jest [...] decydującą przyczyną tego, że wewnątrz nowoczesności teraz sztuka sama jest w stanie przejąć funkcję, która przedtem przypadała jedynie wielkim religiom zbawienia ${ }^{46}$.

red. G. von Graevenitz, Stuttgart-Weimar 1999, s. 52-68; oraz w tej samej książce artykuł Lindy Simonis, Reflexionen der Moderne im Zeichen von Kunst. Max Weber und Georg Simmel zwischen Entzauberung und Ästhetisierung, s. 612-632. Masahiro Noguchi (Kampf um Kultur. Max Webers Theorie der Politik aus der Sicht seiner Kultursoziologie, Berlin 2005, s. 107-137) z kolei przeciwstawia sobie „estetyczny panteizm” Simmla i ,antagonistyczny politeizm” Webera. Nieco inaczej poprowadzoną i wzbogaconą o odniesienie do koncepcji Emila Durkheima analizę porównawczą zawiera także praca Wernera Gepharta, Bilder der Moderne. Studien zur einer Soziologie der Kunstund Kulturinhalte, Opladen 1998.

45 Rzecz jasna, wiąże się to z o wiele szerszą kwestią roli sztuki w epoce wczesnej nowoczesności (zob. F. Vosskühler, Kunst als Mythos der Moderne, Würzburg 2004; czy R. Kasperowicz, Figury zbawienia? Idea , religii sztuki” $w$ wybranych koncepcjach artystycznych XIX stulecia, Lublin 2010). Czasem zatem, jak stwierdza choćby Annete Simonis (Literarischer Ästhetizismus. Theorie der arabesken und hermetischen Kommunikation der Moderne, Tübingen 2000), uznająca estetyzm za Schlüsselepoche der Moderne, wskazuje się na oddziaływanie literackiego estetyzmu na filozofię kultury Simmla czy Cassiera. Kiedy indziej rozważania o Simmlowskim estetyzmie stanowią tło lub wprowadzenie do analizy innych kwestii, jak u Ingo Stöckmanna (Der Wille zum Willen: der Naturalismus und die Gründung der literarischen Moderne 1880-1900, Berlin-New York 2009), który „estetyczny panteizm” i „,wolę sztuki” Simmla łączy z dyskusjami o dziewiętnastowiecznym naturalizmie. Najważniejsze jest jednak, gdy w monografiach poświęconych autorowi Filozofii pieniądza przyznaje się, że dzieło sztuki i artysta stanowiły dla niego ,paradygmaty kultury”, że w jego filozofii sztuki następowały przejścia od estetyki do etyki, a „symbolika życia” spajała to wszystko z metafizyką. W tym ostatnim zdaniu w istocie strawestowałem tytuły rozdziałów książki Anniki Schlitte, Die Macht...

${ }^{46}$ K. Lichtblau, op. cit., s. 65. Zob. ponadto E. Weiller, Max Weber und die literarische Moderne. Ambivalentne Begegnungen zweier Kultur, Stuttgart-Weimar 1994, zwł. rozdz. 3. Wissenschaft 
Twórczość między innymi Michała Anioła pokazywała zatem, jak w sztuce znoszone zostaje przeciwieństwo między tym, co jednostkowe, a tym, co ogólne, między formą a życiem; a coincidetnia oppositorum w tradycji judeochrześcijańskiej jest istotą boskości.

Pozostając jeszcze w kręgu tego typu zagadnień, należy dodać, że miały one wymiar i konsekwencje etyczne, na co zwróciła uwagę Birgit Recki, analizując Cassirerowską krytykę koncepcji tragiczności Simmla. Nie ma powodu, by szerzej do tego wracać ${ }^{47}$, choć analiza porównawcza ich zapatrywań na sztukę warta jest osobnej pracy, a o poglądy pierwszego z nich spierali się u nas swego czasu i Ryszard Różanowski, i Jacek Sójka ${ }^{48}$. Wskażmy jedynie, że podstawowy zarzut autora Eseju o człowieku pod adresem swego byłego nauczyciela zawierał się w tym, że usamodzielnianie się wytworów kulturalnych nie upoważnia do orzekania o tragedii czy — jak to w okresie późniejszym ujmował Simmel o kryzysie kultury. Przedstawione uzasadnienie takiego stanu rzeczy pomijało bowiem niewyczerpalną spontaniczność ludzkiej aktywności, rozumianą w duchu transcendentalizmu, względem którego opozycję stanowiła Lebensphilosophie. Dla Cassirera to, jak renesans odniósł się do antycznego dziedzictwa, doskonale pokazuje splatanie się tradycji i innowacji — właściwy kulturze jako takiej ciągły proces twórczej transformacji, a nie kryzysu.

W pewnej mierze nadawało to opisowy sens ocenie Jacoba Burckhardta, że miarą wyższej kultury jest jej zdolność do renesansu. Cassirer sam był przy tym wybitnym historykiem filozofii, zwłaszcza odrodzeniowej; Simmel z materią historyczną obchodził się dość swobodnie, wykorzystując ją w swych formalnych analizach. Ten ahistoryzm raził wielu socjologów, a i prace o Michale Aniele czy Rembrandcie trudno zaliczyć do historii sztuki. W badaniach myśli renesansowej zdaje się tkwić jedno ze źródeł Cassierowskiego związania z kulturą etosu wolności, która urzeczywistnia się w procesach komunikacyjnego zapośredniczenia. $Z$ tego punktu widzenia zamiast usztywniać relację ,ja"-formy kultury, trzeba dostrzec w samodzielności tych drugich funkcjonalny warunek samourzeczywistnienia się człowieka. Cassirer odrzucał zatem etykę skupioną na prawie indywidualnym oraz uznanie kultury subiektywnej za istotę kultury, a jego ideał jedności ,ja” i świata obej-

und Kunst: Max Weber und Georgekreis, s. 61-161, w którym autorka analizując między innymi stosunek Simmla i Webera do twórczości tego poety i tegoż kręgu, siłą rzeczy scharakteryzowała ich odmienne widzenie roli sztuki w nowoczesnej kulturze.

${ }^{47}$ Przedstawione i rozważone zostało to w dziesiątym tomie „Prac Kulturoznawczych” (2009), zatytułowanym Kultura i tragiczność; zob. też D. Wolska, Ernst Cassirer ostatni filozof kultury?, [w:] O kulturze i jej poznawaniu, red. S. Bednarek, K. Lukasiewicz, Wrocław 2009, s. 134-141.

48 Zob. R. Różanowski, Filozofia sztuki Ernsta Cassirera, „Studia Filozoficzne” 1980, nr 1, s. 105-120; J. Sójka, W sprawie cassirerowskiej filozofii sztuki, „Studia Filozoficzne” 1980, nr 8, s. 99-112; oraz Ch. Hubig, ,, Tragödie der Kultur” revisited: Carl Dahlhaus' Konzeption des Kunstwerks als Alternativezur Simmel-Cassirer-Kontroverse, https://www.philosophie.tu-darmstadt.de/ media/institut_fuer_philosophie/diesunddas/hubig/downloadshubig/tragoedie_der_kultur_revisited_carl_dahlhaus.pdf (dostęp: 21 września 2018). 
mować miał o wiele więcej niż Simmlowska jednolicie formowana osobowość 49 . Przekonanie o plastyczności człowieka oraz otwartości jego dorobku Cassirer przeciwstawiał zawsze partykularnemu i indywidualnemu uczestnictwu kulturalnemu u autora Filozofii pieniądza. Na potrzeby rozważanych tutaj zagadnień zawężając maksymalnie wyniki analizy porównawczej stanowisk obu tych myślicieli, warto przytoczyć wniosek niemieckiej badaczki, że wybór między ,indywidualistycznym defetyzmem” a „kapryśnym decyzjonizmem”50, jako normatywna konsekwencja pojmowania kultury przez Simmla, jest następstwem jego estetyzmu. Zdradza to już — jej zdaniem - sama kategoria tragedii, przejęta z literaturoznawstwa, nawet jeśli uwzględniać, że była ona sublimacją stosunku do tego, co tragiczne. Ale jeśli, koniec końców, chodziło o uzyskanie względem tego dystansu, to w świetle koncepcji Cassiera obejmowało to tylko jedną z postaci refleksyjności kultury i na dodatek ujętą tak, jakby uzyskanie dzięki temu samoświadomości gwarantowało moralność obcowania z innymi. Estetycznej proweniencji dystans do samego siebie zawodzi jednak wobec ,powagi stanowiska praktycznego”. Niemiecka badaczka uznała zatem, że „estetyzujące” podejście Simmla do zagadnień kultury i etyki doprowadzało do pomijania tego, co w i dla nich najważniejsze.

W końcowej części artykułu Michelangelo als Dichter Simmel przytoczył, wyjątkowo w całości, sonet:

$\mathrm{Z}$ tym sercem $\mathrm{z}$ siarki, $\mathrm{z}$ ciałem jak paczesie,

Z kośćmi jak gdyby ze suchego drzewa,

$\mathrm{Z}$ duszą, co wodzy ni kiełzna nie miewa

W gorączce żądzy i w pragnień bezkresie,

Z rozumem ślepym, chromym, który gnie się

Wśród pęt i sideł, w które świat odziewa -

Nie dziw, że prędzej niż grom, gdy się gniewa,

Płonę od pierwszej skry, którą traf niesie.

Jeśli dla pięknej sztuki (którą duchy

Z nieba przynoszą i którą pokona

Naturę, kto się odda jej trudowi)

${ }^{49}$ Ferdinand Fellmann (Georg Simmels Persönlichkeitsbegriff als Beitrag zur Theorie der Moderne, [w:] Neukantianismus. Perspektiven und Probleme, red. E.W. Orth, H. Holzhey, Würzburg 1991, s. 309-328) dostrzegł w tym uczynienie wzorca z modelu osobowości artystycznej, czemu towarzyszło zdestruowanie dotychczasowego metafizycznego pojmownia kultury jako całości istniejącej niezależnie od międzyludzkich oddziaływań (idem, Das Ende der Kultur: Wie Georg Simmel den Begriff der Kultur soziologisch dekonstruiert, „Zeitschrift für Kulturphilosophie” 2015, nr 1-2, s. 79-94).

${ }^{50}$ Zob. B. Recki, „Tragödie der Kultur” oder ,,dialektische Struktur des Kulturbewußtseins”? Der ethische Kern der Kontroverse zwischen Simmel und Cassirer, „Internationale Zeitschrift für Philosophie" 2000, nr 2, s. 157-175; eadem, Nicht so tragisch...: Simmels Begriff, Theorie und Problem der Kultur in der Kontroverse, „Zeitschrift für Kulturphilosophie” 2015, nr 1-2, s. 41-55; oraz G. Ehrl, Wie „,tragisch” ist Simmels „,Tragödie der Kultur”?, „Simmel Studies” 2005, nr 1, s. 3-37. 
Jam się urodził ni ślepy, ni głuchy,

Pięknu pokrewny ogniem mego łona -

Winien ten, co mnie przeznaczył ogniowi ${ }^{51}$.

Spośród wszystkich wierszy Buonarrotiego najlepiej oddaje on jego potrzebę piękna i zrozumienie jego potęgi, także tej groźnej. Podobnie dla Simmla sztuka — na równi z religią — przeznaczona była dla ludzkiej duszy, co oznaczało, że zawsze trzeba ją ujmować jako coś więcej niż sztukę (Mehr-als-Kunst). Rzutowało to również na pojmowanie kultury przez autora Filozofii pieniądza, które niekiedy spotykało się i spotyka z surowym osądem. Ale kiedy stosunkowo niedawno podważono znaczenie jego dorobku dla dzisiejszego myślenia o kulturze ${ }^{52}$, to nie tylko bardzo zawężono pole oglądu, ale i zlekceważono, że w emfatycznym i zestetyzowanym pojmowaniu kultury, za którym opowiadał się Simmel, zawierało się coś więcej niż tylko wartościowanie. Uzasadniany sposób jego dokonywania przysługiwał bowiem jasności spojrzenia nawet wtedy, gdy odrzuca się oceny, które stanowiły jego wynik.

\section{More than philosophy of art. Simmel on Michelangelo}

\section{Abstract}

Georg Simmel's interest in Michelangelo's art is present in all stages of his academic carrier. He published only two works exclusively on this artist but his name frequently appears through Simmel's lifework. In 1899 he published a short article on Buonarroti's poetry and in 1910 a longer piece appeared where Simmel interpreted his artistic achievement as a philosopher of culture. A year later Simmel published The Concept and Tragedy of Culture where his earlier remarks on Michelangelo are included in the context of art's autonomy and the relation between art, ethics and modernity. Max Weber and Ernst Cassirer argued against Simmel's allegedly emphatic and aesthetic conception of culture.

Keywords: philosophy of culture, art, aestheticism, tragism, religion, ethics, modernity

${ }^{51}$ M.A. Buonarroti, op. cit., s. 89.

52 Zob. A. Clemens, ,,Die Kunst Rembrandts, nicht die eines beliebigen Stümpers”. Georg Simmel als Philosoph der repräsentativen Kultur, „Zeitschrift für Kulturphilosophie” 2015, nr 1-2, s. 22-38. Dlatego właśnie dla tego autora punktem odniesienia są cultural studiem; dlatego zarzucił Simmlowi elitaryzm, apolityczność, normatywizm, przywiązanie do burżuazyjnych w istocie wartości. 


\section{Bibliografia}

Biemann A.D., Michelangelo und die jüdische Moderne. Poetik, Exegese und Narrative, Göttingen 2016.

Brabant D., „Moderner Heraklitismus”. Georg Simmls Arbeit an einer Philosophie der Kunst in Bewegung und Kunstdiskurse in Berlin um 1900, „LMU — Publikationen/Geschichts- und Kunstwissenschaften" 2008, nr 28, http://epub.ub.uni-muenchen.de.

Buonarroti M.A., Poezje, przeł. L. Staff, Warszawa 1956.

Burdorf D., Formdenken als Theorie des lyrischen Kunstwerks: Stefan George und Georg Simmel, [w:] idem, Poetik der Form. Eine Begriffs- und Problemgeschichte, Stuttgart 2001.

Clemens A., „Die Kunst Rembrandts, nicht die eines beliebigen Stümpers”. Georg Simmel als Philosoph der repräsentativen Kultur, „Zeitschrift für Kulturphilosophie” 2015, nr 1-2.

Czakon D., Sztuka w eseistycznym ujęciu Georga Simmla próba syntezy, „Estetyka i Krytyka” 2013, nr 2.

Dewey J., Sztuka jako doświadczenie, przeł. A. Potocki, Wrocław 1975.

Ehrl G., Wie „,tragisch” ist Simmels „,Tragödie der Kultur”?, „Simmles Studies” 2005, nr 1.

Faath U., Mehr-als-Kunst. Zur Kunstphilosophie Georg Simmels, Würzburg 1998.

Fellmann F., Das Ende der Kultur: Wie Georg Simmel den Begriff der Kultur soziologisch dekonstruiert, „Zeitschrift für Kulturphilosophie” 2015, nr 1-2.

Fellmann F., Georg Simmel Persönlichketibegriff als Beitrag zur Theorie der Moderne, [w:] Neukantianismus. Perspektiven und Probleme, red. E.W. Orth, H. Holzhey, Würzburg 1991.

Fritsch D., Georg Simmel im Kino. Die Soziologie des frühen Films und das Abenteuer der Moderne, Bielefeld 2009.

Gephart W., Bilder der Moderne. Studien zu einer Soziologie der Kunst- und Kulturinhalte, Opladen 1998.

Gessner W., Der Schatz im Acker. Georg Simmels Philosophie der Kultur, Weilerswist 2003.

Giacomoni P., Georg Simmel und Italie, „Simmel Studies” 2008, nr 1.

Gipper A., Die Entstehung der Kulturwissenschaft in Deutschland und das Paradigma der italienischen Renaissance w Kultur, [w:] Kultur, Übersetzung, Lebenswelten Beiträge zu aktuellen Paradigmen der Kulturwissenschaften, red. A. Gipper, S. Klenge, Königshausen 2008.

Hebekus U., Der Wille zur Form. Politischer Ästhetizismus bei Georg Simmel, Ernst H. Kantorowicz und Alfred Rosenberg, [w:] Die Souveränität der Literatur. Zum Totalitären der klassischen Moderne 1900-1933, red. U. Hebekus, I. Stöckmann, München 2008.

Heinrich A., Erkenntnistheorie auf dem Weg zur Metaphysik, München 1999.

Hubig Ch., ,,Tragödie der Kultur” revisited: Carl Dahlhaus' Konzeption des Kunstwerks als Alternative zur Simmel-Cassirer-Kontroverse, https://www.philosophie.tu-darmstadt.de/media/ institut_fuer_philosophie/diesunddas/hubig/downloadshubig/tragoedie_der_kultur_revisited_ carl_dahlhaus.pdf.

Hüppe E., Musik und Ethos. Eine soziologisch-ästhetische Spurensuche, [w:] Georg Simmel und das Leben in der Gegenwart, red. R. Lautmann, H. Wienold, Wiesbaden 2018.

Jacob J., Tragische Fülle. Kultur, Erinnerung und Apokalypse bei Georg Simmel, [w:] Apokalypse und Erinnerung in der deutsch-jüdischen Kultur des frühen 20. Jahrhunderts, red. J. Brokoff, Göttingen 2002.

Jain E., Das Rembrandt-Bild bei Georg Simmel, „Zeitschrift für Ästhetik und Allgemeine Kunstwissenschaft" 33, 1988.

Jalbert J.E., Time, Death, and History in Simmel and Heidegger, „Human Studies” 26, 2003.

Junge M., Georg Simmel kompakt, Bielefeld 2009.

Kasperowicz R., Figury zbawienia? Idea ,,religii sztuki” w wybranych koncepcjach artystycznych XIX stulecia, Lublin 2010.

Prace Kulturoznawcze 21, 2017, nr 4

(C) for this edition by CNS 
Kasperowicz R., Zweite, ideale Schöpfung. Sztuka w myśleniu historycznym Jacoba Burckhardta, Lublin 2004.

Kasztelowicz S., Tragicy doby bez ksztattu, Warszawa 1933.

Konsermann R., Der Metaphysiker der Diesseits. Entwickelte Korrespondenzkultur - der Philosoph und Soziologe Georg Simmls in seiner Briefe, „Neue Zürcher Zeitung” 23.09.2008.

Kozicki W., Eros. Fragment z życia i twórczości Michała Anioła, „Krytyka” 1910, t. 2 i 4.

Kozicki W., Michat Aniot, Lwów 1908.

Kölb A., Das Leben der Form: Georg Simmels kunstphilosophischer Versuch über Rembrandt, Wien 1998.

Kösser U., Simmels „Rembrandt”, „Simmel Studies” 2003, nr 2.

Kracauer S., Georg Simmel, „Logos” 9, 1920-1921.

Krech V., Georg Simmels Religionsphilosophie, Tübingen 1998.

Kuhlmann T, Die Sehnsucht des Philosophen nach der Kunst. Produktive Widersprüche im Werk von Georg Simmel [Mikrofiche], Tübingen 1998.

Lash S., Systemy eksperckie czy kontekstowa interpretacja. Kultura i instytucje $w$ zdezorganizowanym kapitalizmie, przeł. J. Konieczny, [w:] U. Beck, A. Gideens, S. Lash, Modernizacja refleksyjna, Warszawa 2009.

Lau V., Erzählen und Verstehen: historische Perspektiven der Hermeneutik, Würzburg 1999.

Lichtblau K., „,Alles Vergängliche ist nur ein Gleichnis”. Zur Eigenart des Ästhetischen im kulturoziologischen Diskurs der Jahrhundertwende, [w:] Kultur und Kulturwissenschaften um 1900, t. 2. Idealismus und Positivismus, red. G. Hübner, R. von Bruch, F.W. Graf, Stuttgart 1997.

Lichtblau K., ,, Innerweltliche Erlösung vom Rationalnen ” und , Reich diabolischer Herrlichkeit”? Zum Verhältnis von Kunst und Religion bei Georg Simmel und Max Weber, [w:] Kunst und Religion. Studien zur Kultursoziologie und Kulturgeschichte, red. V. Krech, [Würzburg] 1999.

Lichtblau K., Zum Stellenwert der ästhetisch-literarischen Moderne in den kultursoziologischen Gegenwartsanalysen von Georg Simmel und Max Weber, [w:] Konzepte der Moderne, red. G. Graevenitz, Stuttgart 1999.

Lukács G., Kultura estetyczna, przeł. E. Cygielska, [w:] idem, Pisma krytyczno-teoretyczne 19081932, Warszawa 1994.

Lukács G., Notizen zu Georg Simmels Vorlesungen, 1906/07 und zur »Kunstsoziologie«, ca. 1909, Berlin 2011.

Łukasiewicz K., Alpy, Włochy i rozumienie kultury, „Prace Kulturoznawcze” 17, 2015.

Mannheim K., Georg Simmel als Philosoph, [w:] Georg Lukács, Karl Mannheim und der Sonntagskreis, red. E. Karádi, E. Vezér, Frankfurt am Main 1985.

Meyer I., Georg Simmels Ästhetik: Autonomiepostulat und soziologische Referenz, Weilerswist 2017.

Motak D., Między transcendencją a immanencją. Religia w myśli Georga Simmla, Kraków 2013.

Niehues-Pröbsting H., Das ,, individuelle Gesetz” in der Kunst. Georg Simmels Ästhetik der Lebensphilosophie, [w:] Kunst gibt zu denken, red. U. Franke et al., Münster 1981.

Nobs M., Der Einheitsgedanke in der Philosophie Georg Simmels, [b.m.w.] 1926.

Noguchi M., Kampf um Kultur. Max Webers Theorie der Politik aus der Sicht seiner Kultursoziololgie, Berlin 2005.

Pilgram P., Der Schauspieler als Symbol moderner Kultur bei Simmel, Kracauer und Plessner, Nürnberg 2010.

Podoksik E., In search of unity: Georg Simmel on Italian cities as works of art, „Theory, Culture and Society" 2012, $\mathrm{nr} 6$.

Przyłębski A., Lis zimowa pora: Heidegger, Simmel i czas, [w:] idem, Duch czy życie? Studia i szkice z filozofii niemieckiej, Poznań 2011.

Recki B., Nicht so tragisch...: Simmels Begriff, Theorie und Problem der Kultur in der Kontroverse, „Zeitschrift für Kulturphilosophie” 2015, nr 1-2. 
Recki B., ,, Tragödie der Kultur” oder ,,dialektische Struktur des Kulturbewußtseins”? Der ethische Kern der Kontroverse zwischen Simmel und Cassirer, „Internationale Zeitschrift für Philosophie” $2000, \mathrm{nr} 2$.

Rodriguez R.A., Nieuchwytny obraz Rembrandta: Georga Simmla filozoficzna próba interpretacji „oeuvre” holenderskiego mistrza, „Rocznik Historii Sztuki” 33, 2008.

Różanowski R., Filozofia sztuki Ernsta Cassirera, „Studia Filozoficzne” 1980, nr 1.

Schlitte A., Die Macht des Geldes und die Symbolik der Kultur, Padeborn 2012.

Schuster G., Ist eine Theorie der Kunst möglich?, „Simmel Studies” 2002, nr 2.

Schwerdt O., Geld und Unsinn. Georg Simmel und der Dadaismus. Eine systematische Studie zu relativistischer Philosophie und Kunst, Leipzig 2012.

Simmel G., Das Problem des Stiles, „Dekorative Kunst. Illustrierte Zeitschrift für Angewandte Kunst" 11, 1908, nr 16.

Simmel G., Die Gesetzmässigkeit im Kunstwerk, „Logos” 3, 1917/1918.

Simmel G., Die kulturgeschichtliche Bedeutng Rodins, [w:] Georg Simmel in Wien, red. D. Frisby, Wien 2000.

Simmel G., Filozofia kultury. Wybór esejów, przeł. W. Kunicki, Kraków 2007.

Simmel G., Filozofia życia. Cztery rozdziaty metafizyczne, przeł. M. Tokarzewska, Warszawa 2007.

Simmel G., Michelangelo als Dichter, „Vossische Zeitung” 1889, nr 36.

Simmel G., Michelangelo. Ein Kapitel zur Metaphysik der Kultur, „Logos” 1910/1911, z. 2.

Simmel G., Most i drzwi, przeł. M. Łukasiewicz, Warszawa 2006.

Simmel G., Über die dritte Dimension in der Kunst, ,Zeitschrift für Ästhetik und Allgemeine Kunstwissenschaft" 1906, z. 1.

Simmel G., Über die Geschichte der Philosophie, [w:] Georg Simmel in Wien, red. D. Frisby, Wien 2000.

Simmel-Handbuch: Begriffe, Hauptwerke, red. H.P. Müller, T. Reitz, Frankfurt am Main 2018.

Simonis A., Literarischer Ästhetizismus. Theorie der arabesken und hermetischen Kommunikation der Moderne, Tübingen 2000.

Simonis L., Reflexionen der Moderne im Zeichen von Kunst. Max Weber und Georg Simmel zwischen Entzauberung und Ästhetisierung, [w:] Konzepte der Moderne, red. G. Graevenitz, Stuttgart 1999.

Siwiec M.K., Twórca a myśl estetyczna Michała Anioła Buonarrotiego, „Filo-Sofija” 2007, nr 1.

Smitmans-Vajda B., Die Bedeutung der bildenden Kunst in der Philosophie Georg Simmels, Aachen 1997.

Sobeski M., Interludia, Kraków-Warszawa 1912.

Sobeski M., Przędziwo Arachny, Kraków-Warszawa 1909.

Sójka J., W sprawie cassirerowskiej filozofii sztuki, „Studia Filozoficzne” 1980, nr 8.

Stöckmann I., Der Wille zum Willen: der Naturalismus und die Gründung der literarischen Moderne 1880-1900, Berlin-New York 2009.

Strich F., Transpozycja pojęcia baroku, przeł. A. Węgrzecki, [w:] Współczesna teoria badań literackich za granica, red. H. Markiewicz, t. 2, Kraków 1976.

Tokarzewska M., Der feste Grund des Unberechenbaren: Georg Simmel zwischen Soziologie und Literatur, Opladen 2010.

Vandenberghe F., La loi individuelle. Une éthique nietzschéo-bergsoniennne, „Simmels Studies” $10,2000, \mathrm{nr} 2$.

Vosskühler F., Kunst als Mythos der Moderne, Würzburg 2004.

Wauschkuhn A., Georg Simmels Rembrandt-Bild. Ein lebensphilosophischer Beitrag zur Rembrandtrezeption in 20. Jahrhundert, Worms 2002.

Weiller E., Max Weber und die literarische Moderne. Ambivalentne Begegnungen zweier Kulturen, Stuttgart-Weimar 1994. 
Wolska D., Ernst Cassirer ostatni filozof kultury?, [w:] O kulturze i jej poznawaniu, red. S. Bednarek, K. Łukasiewicz, Wrocław 2009.

Zeidler-Janiszewska A., Nowoczesność jako postawa i zadanie, [w:] G. Simmel, Most i drzwi, przeł. M. Łukasiewicz, Warszawa 2006.

Prace Kulturoznawcze 21, 2017, nr 4

(C) for this edition by CNS 